\title{
Variation in Responses of Sunflower Cultivars to the Parasitic Weed Broomrape
}

\author{
H. Eizenberg, D. Plakhine, J. Hershenhorn, and Y. Kleifeld, ARO, Newe Ya'ar Research Center, Ramat Yishay, \\ Israel; and B. Rubin, Faculty of Agriculture, Food, and Environmental Science, The Hebrew University of Jerusa- \\ lem, Rehovot, Israel
}

\begin{abstract}
Eizenberg, H., Plakhine, D., Hershenhorn, J., Kleifeld, Y., and Rubin, B. 2004. Variation in responses of sunflower cultivars to the parasitic weed broomrape. Plant Dis. 88:479-484.

Development of four Orobanche species, O. cumana, O. aegyptiaca, O. ramosa, and O. cernua, was compared on resistant and susceptible sunflower cultivars. Sunflower plants were infected by $O$. cumana, O. aegyptiaca, and $O$. ramosa, but not by $O$. сеrnua, in field and greenhouse studies. However, cultivating the hosts and parasites in a polyethylene bag system allowed the observation that sunflower induced $O$. сегnua seed germination. This difference demonstrates that $O$. cеrnua is unique from the other three species. O. cumana, O. aegyptiaca, and O. ramosa attached to and developed tubercles on the susceptible sunflower 'Adi.' On the resistant 'Ambar' sunflower, a greater percentage of tubercles were degenerated or dead than on the susceptible cultivar. Thus, resistance of Ambar appears to manifest during tubercle development. Seed production of Adi sunflower was greatly reduced with infection by $O$. cumana.
\end{abstract}

Additional keywords: Egyptian broomrape, root parasite, sunflower broomrape

The genus Orobanche includes chlorophyll-lacking root parasites that parasitize many dicotyledonous species, causing severe damage to vegetable and field crops worldwide (16). Orobanche cumana, O. aegyptiaca, $O$. ramosa, and $O$. cernua are noxious parasitic weeds that infest most of the agricultural areas in Israel $(4,16)$. Sunflower broomrape (O. cumana Wallr.) and Egyptian broomrape (O. aegyptiaca Pers.) are the two Orobanche spp. that parasitize sunflower (Helianthus annuus L.) in Israel (4).

The species $O$. cumana corresponds in Spain to O. cernua (1). Katzir et al. (13) confirmed that $O$. cumana and $O$. cernua in Israel are two different species based on random amplified polymorphic DNA (RAPD) markers. In addition, in Israel, the host range of $O$. cernua and $O$. cumana differs: $O$. cumana parasitizes mainly sunflower, whereas $O$. cernua parasitizes mainly species from the Solanaceae family (4).

Several crops from various botanical families have been found to be resistant or tolerant to Orobanche spp. $(1,4)$, However, an economically significant level of resistance has been developed only in members of the Fabaceae family (10) and in sunflower $(1,3,6)$. Field tolerance of parsley to $O$. crenata also has been found in Israel (9). In recent years, resistant oil-sunflower

Corresponding author: H. Eizenberg E-mail: eizenber@volcani.agri.gov.il

Accepted for publication 6 December 2003.

Publication no. D-2004-0218-02R

(C) 2004 The American Phytopathological Society cultivars were introduced for commercial production in Eastern Europe; however, after a few seasons, they became heavily infected by $O$. cumana (2). In Bulgaria, it was reported that, between 1927 and 1992, five different races of $O$. cumana developed to overcome five different resistances $\left(\mathrm{O}_{1}\right.$ to $\left.\mathrm{O}_{5}\right)$ in oil-sunflower cultivars that were imported from Eastern Europe (7). The same phenomenon was observed in Spain and, recently, two new resistances $\left(\mathrm{O}_{6}\right.$ and $\left.\mathrm{O}_{7}\right)$ were introduced (1).

Several possible mechanisms have been suggested for the resistance phenomenon, such as (i) secretion of inhibitors (phytoalexins) by the resistant host (17), (ii) increased production of phytotoxins in the host roots in response to Orobanche spp. penetration (5), and (iii) condensation and lignification of the root cell walls and increased activity of specific enzymes involved in the defense response (8). Several wild sunflower species have been found to be resistant to $O$. cumana because of their ability to increase cell wall deposition or vessel occlusion, or to induce cellular disorganization (14).

In Israel, the resistance of sunflower cv. Ambar to O. cumana and O. aegyptiaca is temperature dependent $(3,6)$. High temperatures greater then 26 and $18^{\circ} \mathrm{C}$ (day and night) increase the resistance reaction, whereas low temperatures, lower then 20 and $12^{\circ} \mathrm{C}$ (day and night), break down the resistance. The resistance manifests as a mortality of the Orobanche tubercles after penetration and establishment in the host tissue $(3,6)$. In Spain, sunflower cultivars were highly resistant to $O$. cumana only at $27^{\circ} \mathrm{C}$, but were sensitive at the lower temperature range of 15 to $23^{\circ} \mathrm{C}$ (18).
The objectives of the present study were to (i) compare the responses of resistant and sensitive sunflower cultivars to $O$. ramosa and $O$. cernua infection and to the resistant response that was observed in sunflower infected by $O$. cumana and $O$. aegyptiaca, and (ii) define the host range of Orobanche spp. in resistant and sensitive sunflower cultivars in Israel.

\section{MATERIALS AND METHODS}

Plant material: sunflower. The resistant (R) Ambar and sensitive (S) Adi sunflower cultivars were provided by Dr. Baruch Retig of the ARO, Israel. Both sunflower cultivars were bred from the local cv. D. Y. 3; therefore, the genetic backgrounds of both cultivars are similar (B. Retig, personal communication).

Orobanche spp. O. cumana seed were collected from Orobanche inflorescences parasitizing sunflower plants in the Jezreel Valley in northern Israel; $O$. aegyptiaca and $O$. ramosa seed were collected from Orobanche inflorescences parasitizing tomato and potato plants, respectively, on the Golan Heights in northern Israel; $O$. cernua seed were collected from Orobanche inflorescences parasitizing tomato in Beit Dagan in the central coastal plain of Israel. The inflorescences were dried in a greenhouse for 60 days and the seed were separated with $300-\mu \mathrm{m}$ sieves, then stored in the dark at $4^{\circ} \mathrm{C}$. The germination potential of the seed was tested in the presence of GR24 (a synthetic strigol analog germination stimulant) at $10 \mathrm{ppm}$. After a preconditioning period of 12 days at $24^{\circ} \mathrm{C}$, germination rates of seed of $O$. cumana, $O$. aegyptiaca, $O$. ramosa, and $O$. cernua were $88,80,60$, and $75 \%$, respectively.

Field studies. Experiments were started in April 1997 and April 1998 at the Volcani Center, Bet Dagan. The field was sprinkler irrigated to a depth of $60 \mathrm{~cm}$, plowed, fertilized, and $1.93-\mathrm{m}$-wide beds were prepared. The soil was fumigated with methyl bromide at $500 \mathrm{~kg} / \mathrm{ha}$ and was artificially infested, in two parallel furrow rows $90 \mathrm{~cm}$ apart, with $O$. cumana, $O$. aegyptiaca, $O$. ramosa, or $O$. cernua seed at a rate of 200 $\mathrm{mg}$ of seeds mixed with $16 \mathrm{ml}$ of fine sand per meter row. The seed were placed at a furrow-row depth of $8 \mathrm{~cm}$ in 20-m-long plots. Half $(10 \mathrm{~m})$ of each plot was sown with $\mathrm{R}$ sunflower seed and the other half with $\mathrm{S}$ sunflower seed. Control plots without broomrape seed were sown with $\mathrm{R}$ and $\mathrm{S}$ sunflower cultivars as above. The sunflowers were sown manually and were 
thinned to 3 plants/m at the four- to sixtrue-leaf stage. Orobanche shoots were counted weekly throughout the season. Sunflower vigor was estimated visually using a scale of 0 (entirely dead plants) to 100 (healthy, green and vigorous plants) compared with the noninfested control plots. For example, estimation of $50 \%$ vigor indicated that a plant was stunted by approximately $50 \%$ compared with the noninfested control, or a plant that showed yellowing or withering symptoms, or a combination of those symptoms. The heads of the sunflower plants from each plot $\left(20 \mathrm{~m}^{2}\right)$ were collected and weighed after their seed had ripened.

Greenhouse studies. Experiments were conducted under greenhouse conditions at 21 and $29^{\circ} \mathrm{C}$ (night and day) with an average of $14 \mathrm{~h}$ of natural daylight. The experiments were conducted in 18-cm-diameter pots containing vermiculite and air-dried soil (medium-heavy clay-loam soil; $55 \%$ clay, $23 \%$ silt, $20 \%$ sand, $2 \%$ organic matter, $\mathrm{pH} 7.1 ; 1: 1 \mathrm{vol} / \mathrm{vol})$. Soil containing $\mathrm{N}: \mathrm{P}: \mathrm{K} \quad(20: 20: 20$, wt/wt/wt) commercial slow-release fertilizer at $1 \mathrm{~g} / \mathrm{kg}$ soil, and $O$. cumana, O. aegyptiaca, O. ramosa, or $O$. cernua seed at $5 \mathrm{mg} / \mathrm{kg}$ soil were mixed in a cement mixer for $10 \mathrm{~min}$. The control pots did not contain Orobanche seed.

Three to five seed of R or S sunflower were planted in each pot and thinned to one seedling per pot after emergence. Treatments included $\mathrm{R}$ or $\mathrm{S}$ sunflower plants grown in pots inoculated with each of the Orobanche spp., and a noninfested control. The pots were drip irrigated as needed. The Orobanche shoots that emerged above the soil were counted weekly. Sunflower vigor was estimated using a scale of 0 to 100 , as above. Inhibition was characterized as withering and yellowing leaves, small plants, and small diameter of the sunflower inflorescence. At the end of the experiment, 90 days after planting, sunflower shoots were harvested, dried at $70^{\circ} \mathrm{C}$ for $48 \mathrm{~h}$, and measured as a total dry sunflower biomass. The sunflower roots were washed of soil and healthy and degenerate parasites (3) attached to the roots were counted, dried at $70^{\circ} \mathrm{C}$ for $48 \mathrm{~h}$, and measured as a total broomrape biomass.

Polyethylene bag studies. Polyethylene bags (PEB) were prepared according to Parker and Dixon (15) with modifications according to Eizenberg et al. (6). This method facilitates continuous observation of the host roots and monitoring of the various stages of Orobanche development and the parasitism process: seed germination, attachment of the germ tubes to the host roots, spider formation, and the appearance of parasite spikes.

$\mathrm{R}$ and $\mathrm{S}$ sunflower seedlings were germinated in a vermiculite medium in a growth chamber under 21 and $29^{\circ} \mathrm{C}$ (night and day) temperatures. At the cotyledon stage, 7 to 10 days after planting, the seedlings were transferred gently into PEB containing fiberglass filter paper (GF/A, Whatman) onto which sterilized Orobanche seed had been scattered. Two sunflower seedlings were placed in each bag, with each root system on half of each GF/A sheet, together with sterilized $O$. cumana, O. aegyptiaca, O. ramosa, or $O$. cernua seed. The plants were nourished with half-strength Hoagland nutrient solution (12).

Sunflower plants were grown in a growth chamber under 21 and $29^{\circ} \mathrm{C}$ (night and day) temperatures. The responses of $\mathrm{R}$ and $\mathrm{S}$ sunflower plants to the Orobanche spp. were expressed as an R/S ratio. This value was obtained for each stage of the Orobanche parasitism by dividing the percentage of germinated seed, attached germs, tubercle production, or degenerate parasites observed on the $\mathrm{R}$ sunflower roots by the number observed on the $S$ roots. This treatment of the data enabled comparison of compatibility of the sensitive sunflower to each development stage of each of the Orobanche spp. with that of the resistant one. R and S sunflower plants were grown in PEB with no Orobanche seed as untreated controls. Observations were carried out with a binocular microscope (DZ, Zeiss, Germany) at $\times 40$ magnification, in order to observe and monitor the events of seed germination and the successful continuation of the parasitism process. Microscopic observations covered the area of the main sunflower root, on which the numbers of broomrape seed, germinating seed, tubercles, spikes, and degenerate attachments were recorded.

Experimental design and analysis. The field study was arranged in a completely randomized split plot design, with five replications, with Orobanche spp. serving as a main plot and sunflower cultivars as a subplot. The greenhouse experiments were arranged in a completely randomized design (Orobanche spp. and sunflower cultivars) with six replications for each treatment. The cultivation in the PEB experiment was performed in a completely randomized design with two factors (Orobanche spp. and sunflower cultivar) and with eight replications for each treatment. The experiment was repeated twice. The results were subjected to analysis of variance by means of the JMP software (version 4.0.3; SAS Institute Inc., Cary, NC). Means were separated by least significant difference based on a Tukey Kremer Honestly Significant Different (HSD) test $(P \leq 0.05)$.

\section{RESULTS}

Field study. The year-experiment interaction for the field experiments conducted in 1997 and 1998 was not significant; therefore, the results obtained from the two experiments were combined. Differences were observed in the response of $\mathrm{R}$ and $\mathrm{S}$ sunflower cultivars to Orobanche spp. infection (Table 1).

By 74 days after planting (DAP), the numbers of Orobanche shoots that emerged around $\mathrm{R}$ sunflower plants infected with $O$. cumana, O. aegyptiaca, and $O$. ramosa were 1.5 to 6 shoots per plant, but this infection level did not cause any damage to the $\mathrm{R}$ sunflower plants, which developed normally throughout the experiment. Moreover, broomrape shoots did not begin to emerge around the $\mathrm{R}$ plants until 60 DAP; whereas, around the S plants, $O$. cumana shoots began to emerge 32 DAP, and those of $O$. aegyptiaca and $O$. ramosa after 46 DAP. The infection levels in the $\mathrm{S}$ sunflower plants grown in the broomrape-

Table 1. Orobanche spp. parasitism and development of sunflowers of resistant cv. Ambar (R) and sensitive cv. Adi (S), grown in the field in spring 1997 and 1998

\begin{tabular}{|c|c|c|c|c|c|c|c|c|c|}
\hline \multirow[b]{2}{*}{ Orobanche spp. } & \multirow[b]{2}{*}{ Sunflower } & \multicolumn{4}{|c|}{ Orobanche parasitism (Shoots/plant) } & \multicolumn{4}{|c|}{ Sunflower development $(\%)^{\text {b }}$} \\
\hline & & $32 \mathrm{DAP}^{\mathrm{a}}$ & 46 DAP & 60 DAP & 74 DAP & 32 DAP & 53 DAP & 74 DAP & 95 DAP \\
\hline \multirow[t]{2}{*}{ O. cumana } & $\mathrm{R}$ & 0 & 0 & 0.5 & 1.5 & 96 & 100 & 96 & 100 \\
\hline & S & 4.6 & 8 & 24 & 45 & 100 & 100 & 72 & 42 \\
\hline \multirow[t]{2}{*}{ O. aegyptiaca } & $\mathrm{R}$ & 0 & 0 & 1 & 6 & 100 & 96 & 98 & 98 \\
\hline & $\mathrm{S}$ & 0 & 5 & 18 & 31 & 98 & 100 & 84 & 68 \\
\hline \multirow{2}{*}{ O. ramosa } & $\mathrm{R}$ & 0 & 0 & 2 & 5 & 100 & 98 & 96 & 98 \\
\hline & $\mathrm{S}$ & 0 & 6 & 22 & 28 & 96 & 100 & 80 & 64 \\
\hline \multirow[t]{2}{*}{ о. сегпиа } & $\mathrm{R}$ & 0 & 0 & 0 & 0 & 100 & 100 & 100 & 97 \\
\hline & $\mathrm{S}$ & 0 & 0 & 0 & 0 & 100 & 97 & 96 & 100 \\
\hline $\operatorname{LSD}(0.05)^{\mathrm{c}}$ & $\ldots$ & 1.8 & 3.2 & 6.7 & 9.4 & 5.8 & 5.3 & 7.1 & 9.3 \\
\hline
\end{tabular}

${ }^{\mathrm{a}} \mathrm{DAP}=$ days after planting. Data are means obtained from 10 replications in 2 years of experiments.

${ }^{\mathrm{b}}$ Sunflower development on a scale of 0 to 100 , with 0 representing dead plants and 100 representing healthy plants, compared with the noninfested control.

${ }^{c}$ Means were separated by least significant difference (LSD) based on Tukey-Kramer Honestly Significant Difference (HSD) test, $(P \leq 0.05)$. 
infested plots increased considerably in the course of time, and reached 28 to 45 Orobanche shoots per plant in the plots infested with $O$. cumana, O. aegyptiaca, and $O$. ramosa. Orobanche infection retarded the development of the $S$ sunflower plants. The inhibition was characterized as withering and yellowing leaves. Inhibition was first observed 74 DAP and had increased by 95 DAP, when sunflower development in plots infested with $O$. aegyptiaca, $O$. ramosa, and $O$. cumana was 42,68 , and $64 \%$, respectively, of that of the S plants in the noninfested control plots. The most severe damage was observed in the $\mathrm{S}$ sunflower plants grown in the O. cumanainfected plots, in which the damage was manifested as plant withering, stunting, and development of undersized sunflower inflorescences that produced empty kernels. O. cernua shoots did not emerge in either the R or the S sunflowers; therefore, no damage to the plants could be observed

Sunflower yield was measured in order to determine the effect of the parasitism on sunflower seed production. Seed production in $O$. cumana-infected $\mathrm{S}$ sunflowers was only $8 \%$ of that in the S plants grown (Table 1).

in the noninfested control plots (Fig. 1), and $O$. aegyptiaca and $O$. ramosa reduced seed production by 26 and $22 \%$, respectively, in S plants compared with the controls. None of the three Orobanche spp. affected the seed production of the $\mathrm{R}$ sunflowers grown in the infested soil and their yields were the same as that of the plants grown in the noninfested plots. There also was no difference in seed production between the $\mathrm{R}$ and $\mathrm{S}$ sunflower plants grown in the $O$. cernua-infested and noninfested plots.

Greenhouse studies. There was no experiment-treatment interaction between the greenhouse experiments; therefore, the results of both experiments were combined. The $\mathrm{R}$ plants were not significantly infected by any of the tested Orobanche spp., in contrast with the high infection levels observed in the $\mathrm{S}$ plants in the pots inoculated with $O$. cumana, O. aegyptiaca, or $O$. ramosa (Table 2). On the S plants, $O$. cumana infection was first observed 32 DAP, and $O$. aegyptiaca and $O$. ramosa infections at 46 DAP. The infection levels of the S plants 74 DAP reached 26 to 48 inflorescences per plant, for $O$. cumana, $O$. aegyptiaca, and $O$. ramosa. No O. cernua

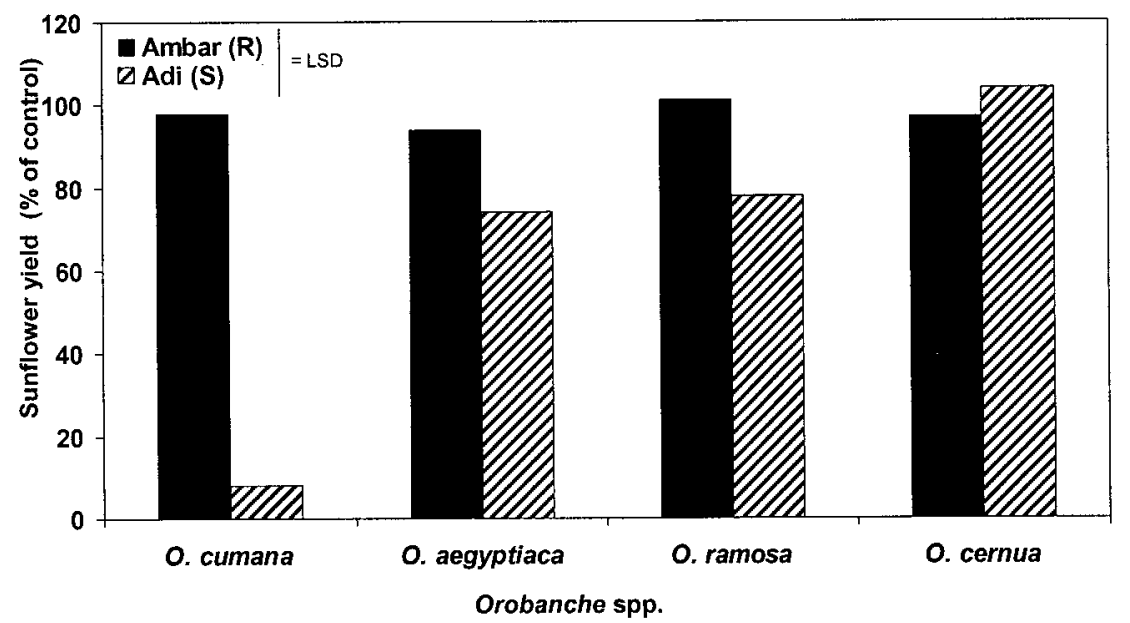

Fig. 1. Resistant (R) and susceptible (S) sunflower yields (percentage of noninfested control) grown under field conditions. Sunflowers were grown in spring 1997 and 1998. The data represent means of 10 replications from 2 years of experiments. Vertical bar represents least significant difference (LSD) based on Tukey-Kramer Honestly Significant Difference test $(P \leq 0.05)$. infection could be detected on the roots of either R or S plants throughout the experiments. The development of the infected $S$ plants was significantly inhibited by each of the three Orobanche spp., whereas the same parasite species had no effect on the development of the $\mathrm{R}$ plants; the latter continued to develop normally in infested pots, with no difference from those growing in the noninfested pots (Table 2). $O$. cumana inhibited development of S plants more severely than did $O$. aegyptiaca or $O$. ramosa, as observed at 46 DAP. The vigor and appearance of the plants grown in the pots infested with $O$. cumana continued to deteriorate and, at 74 DAP, their development was evaluated at $24 \%$ of noninfested, compared with 50 and $45 \%$ for the plants grown in pots infested with $O$. aegyptiaca and $O$. ramosa, respectively. $O$. cernua did not affect either $\mathrm{R}$ or $\mathrm{S}$ sunflower plants, which continued to develop normally (Table 2).

Parasite attachments on the roots were counted at the end of the experiment. The proportions of degenerate attachments in the $O$. cumana-, O. aegyptiaca-, and $O$. ramosa-infected $\mathrm{R}$ sunflower roots were high, compared with a low proportion of degenerated attachments found on the $\mathrm{S}$ sunflower plant roots (Fig. 2): between 78 to $87 \%$ of the attachments found on the $\mathrm{R}$ sunflower plant roots grown in the pots infested with $O$. cumana, O. aegyptiaca, and $O$. ramosa were degenerate or dead, compared with 8 to $20 \%$ of those on the S plant roots in similar pots. No $O$. cernua attachments were observed on either the $\mathrm{R}$ or the $\mathrm{S}$ sunflower roots grown in the $O$. cernua-infected pots (Fig. 2).

The total dry biomass, including healthy and degenerate attachments as well as the shoots of each of the tested Orobanche spp. (O. cumana, O. aegyptiaca, and $O$. ramosa) on the roots of S sunflower plants was much higher than that of the same species collected from the roots of the $R$ sunflower plants, and there was no difference among the Orobanche spp. (Fig. 3).

Differences were observed between the dry biomasses of $\mathrm{R}$ and $\mathrm{S}$ sunflower plants infected with Orobanche spp. (Fig. 4).

Table 2. Orobanche spp. parasitism and development of sunflowers of resistant cv. Ambar (R) and the sensitive cv. Adi (S), grown in pots in the greenhouse under controlled conditions of 21 and $29^{\circ} \mathrm{C}$ (night and day)

\begin{tabular}{|c|c|c|c|c|c|c|c|c|c|}
\hline \multirow[b]{2}{*}{ Orobanche spp. } & \multirow[b]{2}{*}{ Sunflower } & \multicolumn{4}{|c|}{ Orobanche parasitism (Shoots/plant) } & \multicolumn{4}{|c|}{ Sunflower development $(\%)^{\mathrm{b}}$} \\
\hline & & 32 DAPa & 46 DAP & 60 DAP & 74 DAP & 32 DAP & 46 DAP & 60 DAP & 74 DAP \\
\hline \multirow[t]{2}{*}{ O. cumana } & $\mathrm{R}$ & 0 & 0 & 0.5 & 1.5 & 100 & 98 & 96 & 96 \\
\hline & $\mathrm{S}$ & 4.1 & 11 & 26 & 48 & 100 & 64 & 40 & 24 \\
\hline \multirow[t]{2}{*}{ O. aegyptiaca } & $\mathrm{R}$ & 0 & 0 & 0 & 5 & 96 & 96 & 100 & 96 \\
\hline & $\mathrm{S}$ & 0 & 3.4 & 17.2 & 33 & 98 & 76 & 62 & 50 \\
\hline \multirow{2}{*}{ O. ramosa } & $\mathrm{R}$ & 0 & 0 & 0 & 3 & 96 & 98 & 100 & 100 \\
\hline & $\mathrm{S}$ & 0 & 2.8 & 12 & 26 & 98 & 82 & 65 & 45 \\
\hline \multirow[t]{2}{*}{ O. сегпиа } & $\mathrm{R}$ & 0 & 0 & 0 & 0 & 100 & 100 & 94 & 100 \\
\hline & $\mathrm{S}$ & 0 & 0 & 0 & 0 & 97 & 100 & 97 & 99 \\
\hline $\operatorname{LSD}(0.05)^{\mathrm{c}}$ & $\ldots$ & 1.2 & 2.4 & 5.9 & 7.5 & 5.6 & 8.3 & 7.7 & 8.6 \\
\hline
\end{tabular}

${ }^{\mathrm{a}} \mathrm{DAP}=$ days after planting. Data are means obtained from 12 replications in two experiments.

b Sunflower development on a scale of 0 to 100 , with 0 representing dead plants and 100 representing healthy plants, compared with the noninfested control.

${ }^{c}$ Means were separated by least significant difference (LSD) based on Tukey-Kramer Honestly Significant Difference (HSD) test, $(P \leq 0.05)$. 
Whereas the R sunflower dry biomass was not influenced by any of the three Orobanche spp. infections, the dry weights of $\mathrm{S}$ plants infected with $O$. cumana, $O$. aegyptiaca, and O. ramosa were 24 to $54 \%$ of the dry weight of the noninfested controls (Fig. 4). No differences in dry weight were observed between the $\mathrm{R}$ and $\mathrm{S}$ sunflower plants grown in O. cernua-infested pots and those grown in noninfested control pots.

PEB studies. No experiment-treatment interaction between the experiments conducted in the PEB system was found; therefore, results of the experiments were combined. The developmental stagesgermination, attachments, tubercle development, or tubercles mortality-of $O$. cumana, O. aegyptiaca, O. ramosa, and $O$. cernua on the roots of the $\mathrm{R}$ and the $\mathrm{S}$ sunflower plants are summarized in Table 3. Orobanche seed germinated at rates of 67 to $92 \%$ for O. cumana, O. aegyptiaca, $O$. ramosa, and O. cernua on the R cultivar and at rates of 70 to $88 \%$ on the S cultivar. However, the R/S ratios in the germination stage were not significantly different from 1 for each of the four Orobanche spp.

No significant differences were observed among O. cumana, O. aegyptiaca, and $O$. ramosa in attachment rate as a percentage of the germinated seed (Table 3 ). The R/S ratios were not significantly different from unity at this stage, indicating that no differences exist between the $\mathrm{R}$ and $S$ sunflower plants in the attachment rates of $O$. cumana, O. aegyptiaca, and $O$. ramosa to their roots. Few $O$. cernua at-

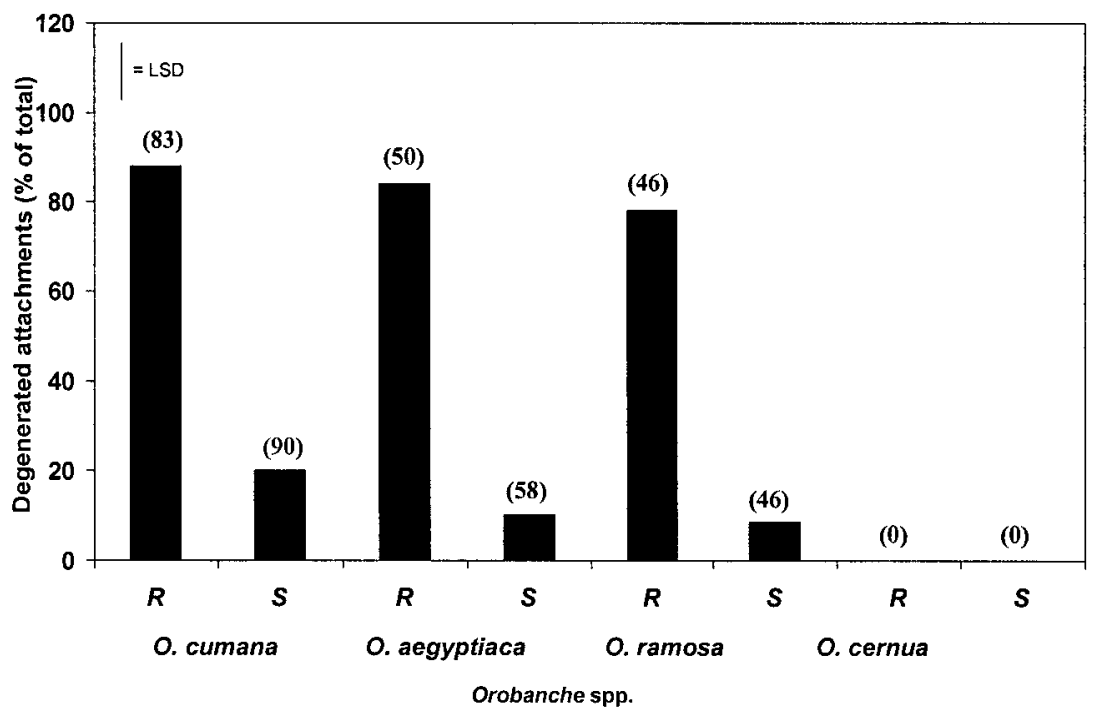

Fig. 2. Degenerate attachments (percentage of total attachments) of Orobanche spp. parasitizing resistant (R) and susceptible (S) sunflowers, 80 days after planting. Pots were kept under controlled conditions ( 21 and $29^{\circ} \mathrm{C}$, night and day). Numbers in parentheses are total attachments. Vertical bar represents least significant difference (LSD) based on Tukey-Kramer Honestly Significant Difference test $(P \leq 0.05)$.

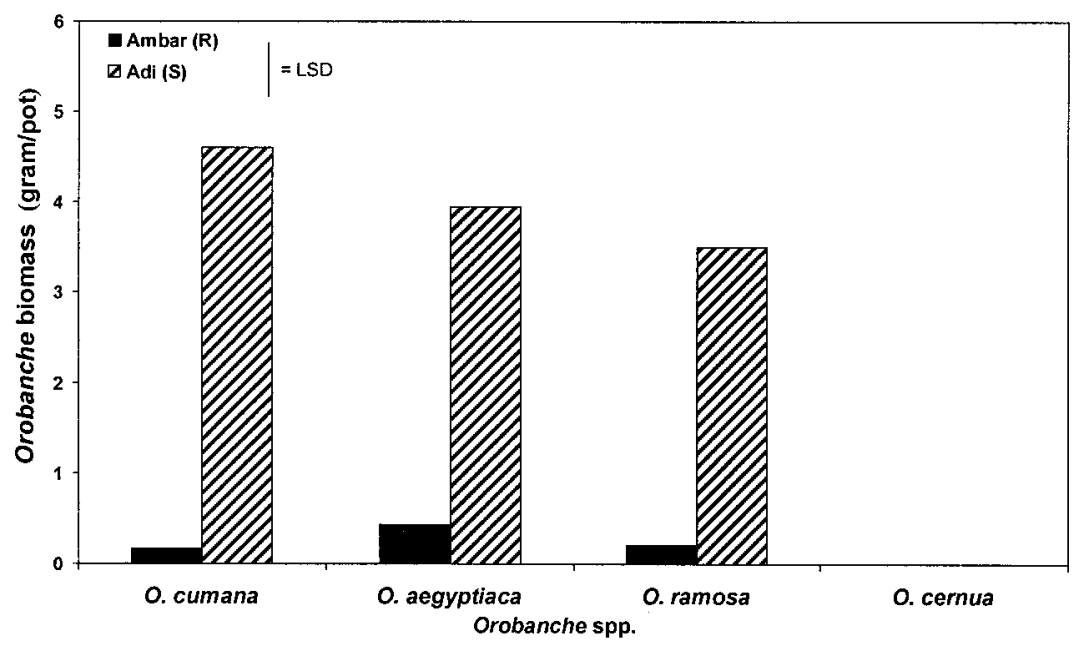

Fig. 3. Orobanche spp. dry biomass in resistant (R) and susceptible (S) sunflowers in pots grown under greenhouse conditions. The data are the means of 12 replications from two experiments. Vertical bar represents least significant difference (LSD) based on Tukey-Kramer Honestly Significant Difference test $(P \leq 0.05)$. tachments were observed on either the R or $S$ roots and $R / S$ ratios were not computed for attachments and further parasitism stages. The $O$. cernua germ tubes that succeeded in reaching the roots formed an initial contact that soon ceased to develop and the $O$. cernua germs died.

The percent of healthy developed tubercles of $O$. cumana, $O$. aegyptiaca, and $O$. ramosa were greater on the $\mathrm{S}$ than on the $\mathrm{R}$ plant roots, as indicated by $\mathrm{R} / \mathrm{S}$ ratios $<1$ (Table 3). However, the R/S ratio of mortalities of tubercles of the same Orobanche spp. was $>1$, indicating that more degenerate attachments were found on the $\mathrm{R}$ than on the $\mathrm{S}$ sunflower roots. The R/S ratio for tubercles mortality was greatest in $O$. cumana compared with $O$. aegyptiaca or $O$. ramosa, indicating more compatibility between the resistance mechanism of $O$. cumana and sunflower than $O$. aegyptiaca or O. ramosa.

\section{DISCUSSION}

The results of the present study indicate that the resistance response of $O$. ramosa on resistant sunflower is similar to the response observed in $O$. cumana and in $O$. aegyptiaca $(3,6)$. However the response of $O$. cernua to $\mathrm{R}$ and $\mathrm{S}$ sunflower differs. The roots of both $\mathrm{R}$ and $\mathrm{S}$ cultivars induce seed germination of each of the four Orobanche spp., and no difference in Orobanche seed germination rate was observed between the $R$ and the $S$ sunflowers. These results suggest that the incompatibility between sunflower and $O$. cernua is not blocked at the Orobanche seed germination stage.

The attachments on the roots of the $\mathrm{S}$ sunflower cv. Adi continued to develop normally, producing inflorescences and viable seed of three of the Orobanche spp. tested. $O$. cernua germinated but failed to establish in either the $\mathrm{S}$ or $\mathrm{R}$ sunflower root tissues.

This study demonstrates that, in Israel, $O$. cernua differs from $O$. cumana in its host range. The incompatibility reaction between the host and $O$. cernua was evident in the early stage of parasitism, attempting penetration into the host root tissue. Our results support the findings of a previous study (13), which used RAPD marker techniques to prove that there were differences between these two Orobanche spp. In contrast to the mode of the sunflower-O. cernua incompatibility reaction, $O$. ramosa succeeded in penetrating both $\mathrm{R}$ and $\mathrm{S}$ sunflower roots, but the incompatibility reaction occurred only on the $\mathrm{R}$ roots. With $O$. ramosa, parasitism was limited at the tubercle stage or, in some cases, even later, at the stage of inflorescence apex formation.

$O$. ramosa successfully penetrated the host tissues, after which most of the attachments on the $\mathrm{R}$ sunflower roots degenerated and died. This resistant response was observed in the R sunflower cv. Am- 
bar in the three Orobanche spp. that parasitized sunflower, but not with O. cernua.

Previous studies on the resistance of sunflower to Orobanche spp. addressed the resistance mechanisms to $O$. cumana races A-C (1). The mechanisms are described as hypersensitivity and cortex necrosis $\left(\mathrm{Or}_{2}\right)$, compounds, and condensation of cell walls by lignification $\left(\mathrm{Or}_{3}\right)(5,8,10,14)$. Involvement of 7-hydroxylated simple coumarins in the resistant response of sunflower to $O$. cernua has been proposed (17). Histological studies on the roots of Orobanche spp.resistant purple vetch showed that the haustorium penetrated directly through the epidermis and cortex but stopped at the endodermis cells $(8,10)$. Most of those studies discuss resistance mechanisms that are initiated shortly after the parasite penetrated the host root tissue. The resistant reaction described in the present study is different. Parasite mortality occurs at a later stage of the parasitism process (e.g., at the tubercles stage or even at shoot formation and emergence). The resistant response of cv. Ambar toward O. ramosa was found in this study to be similar to the response to $O$. cumana and $O$. aegyptiaca; namely, degeneration and death of the parasite after successful germination, attachment, penetration, and establishment.

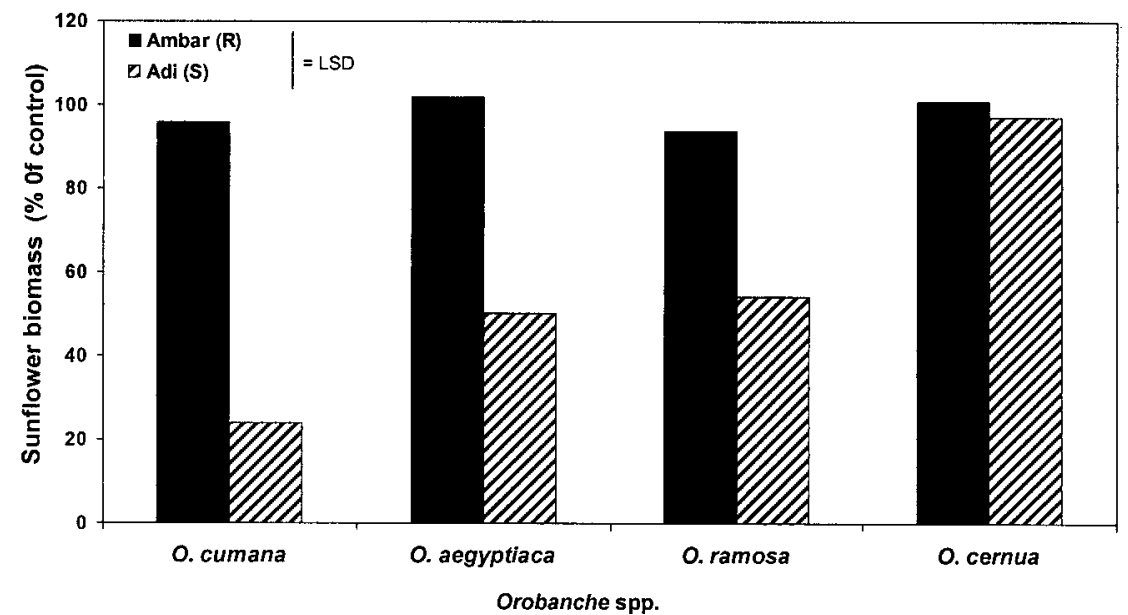

Fig. 4. Resistant 'Ambar' and sensitive 'Adi' sunflower dry weights (percentage of those of noninfested sunflower plants) grown in pots infested with Orobanche spp. under controlled greenhouse conditions. The data are the means of 12 replications from two experiments. Vertical bar represents least significant difference (LSD) based on Tukey-Kramer Honestly Significant Difference test $(P \leq$ $0.05)$. sponse is a general characteristic of the resistance mechanism of Ambar regardless of the Orobanche spp., except in the case of O. cernua.

Others researchers have proposed that the resistance mechanism of sunflower type $\mathrm{Or}_{4}$ or $\mathrm{O}_{\mathrm{r}_{5}}$ is a result of increased phytotoxins or phytoalexins production $(1,17)$. It can be hypothesized that the resistance mechanism of the sunflower cv. Ambar also may be explained by resistance types $\mathrm{Or}_{4}$ or $\mathrm{Or}_{5}(5)$.

Field studies showed that $O$. cumana virulence on the sensitive cultivar was higher than the virulence of $O$. aegyptiaca and $O$. ramosa, resulting in severe damage and yield reduction in O. cumana-infested fields. The resistant sunflower Ambar and the susceptible sunflower Adi were selected for this study due to their resistance and susceptibility, respectively, only to $O$. cumana. Thus, it might explain the high infection level due to the high compatibility between the sensitive sunflower and $O$. cumana.

The present study has identified the pathogenicity and virulence potential of $O$. ramosa and O. cernua to Ambar and Adi sunflower cultivars. The results have enabled us to include resistant sunflower cultivars in crop rotations in O. cumana-, involvement of Orobanche-toxic phenolic

It can be concluded that this type of re-

Table 3. Orobanche spp. development at difference parasitism stages on resistant (R) and susceptible (S) sunflower cultivars

\begin{tabular}{|c|c|c|c|c|c|c|c|c|c|c|c|c|}
\hline \multirow[b]{2}{*}{ Orobanche spp. } & \multicolumn{3}{|c|}{ Germination $(\%$ of seed $)$} & \multicolumn{3}{|c|}{ Attachments (\% of germs) } & \multicolumn{3}{|c|}{ Tubercles (\% of attachments) } & \multicolumn{3}{|c|}{ Mortality (\% of tubercles) } \\
\hline & $\mathbf{R}$ & $\mathbf{S}$ & $\mathbf{R} / \mathbf{S}$ & $\mathbf{R}$ & $\mathbf{S}$ & $\mathbf{R} / \mathbf{S}$ & $\mathbf{R}$ & $\mathbf{S}$ & $\mathbf{R} / \mathbf{S}$ & $\mathbf{R}$ & $\mathbf{S}$ & $\mathbf{R} / \mathbf{S}$ \\
\hline O. cumana & $85^{\mathrm{a}}$ & 87 & 0.98 & 36 & 37 & 0.97 & 27 & 82 & 0.33 & 93 & 14 & 6.64 \\
\hline O. aegyptiaca & 74 & 72 & 1.03 & 38 & 40 & 0.95 & 25 & 81 & 0.30 & 88 & 20 & 4.4 \\
\hline O. ramosa & 67 & 70 & 0.96 & 30 & 32.4 & 0.93 & 21 & 72 & 0.29 & 85 & 22 & 3.86 \\
\hline O. сегпиа & 92 & 88 & 1.05 & 1.2 & 0.8 & N/A & N/A & N/A & N/A & N/A & N/A & N/A \\
\hline $\operatorname{LSD}(0.05)^{\mathrm{b}}$ & 8.7 & 7.5 & 0.14 & 9.3 & 9.1 & 0.08 & 8.2 & 12.3 & 0.09 & 9.0 & 8.7 & 0.74 \\
\hline
\end{tabular}

${ }^{a}$ Data were arcsine transformed but the true values are presented. $\mathrm{R} / \mathrm{S}=$ ratio of the rate of each developmental stage for the susceptible cultivar divided by the resistant cultivar; N/A = no $O$. cernua tubercles were observed.

${ }^{\mathrm{b}}$ Means were separated by least significant difference (LSD) based on Tukey-Kramer Honestly Significant Difference (HSD) test, $(P \leq 0.05)$.
$O$. aegyptiaca-, and $O$. ramosa-infested fields in Israel. The findings of this study also enabled us to recommend that sunflower growers plant resistant and sensitive sunflower cultivars in $O$. cernua-infested fields. This broomrape species may serve as a "trap crop" (11) in order to reduce broomrape soil seed bank.

\section{ACKNOWLEDGMENTS}

We thank B. Retig, ARO, Israel for his valuable advice and for the sunflower cvs. Ambar and Adi seed, and Z. Tanaami, ARO, for his technical assistance.

\section{LITERATURE CITED}

1. Alonso, L. C. 1998. Resistance to Orobanche and resistance breeding: a review. Pages 233 257 in: Proc. 4th Int. Workshop Orobanche Res. K. Wegmann, L. J. Musselman, and D. M. Joel, eds. Institute for Wheat and Sunflower, Dobroudja, Albena, Bulgaria.

2. Antonova, T. S. 1994. Biochemical aspects of the development of new virulent forms in the Moldavian population (race C) of Orobanche cumana Wallr. against the background of resistant sunflower cultivars. Pages 290-292 in: Proc. 3rd Int. Workshop Orobanche and Related Striga Res. A. H. Pieterse, J. A. C. Verkleij, and S. J. ter Borg, eds. Royal Tropical Institute, Amsterdam, The Netherlands.

3. Eizenberg, H., Hershenhorn, J., Plakhine, D. Shtienberg, D., Kleifeld, Y., and Rubin, B. Effect of temperature on susceptibility of sunflower varieties to Orobanche cumana and $O$. aegyptiaca. Weed Sci. 57:279-286.

4. Eizenberg, H., and Joel, D. M. 2001. Orobanche in Israeli agriculture. Workshop of COST Action 849, Parasitic Plant Management in Sustainable Agriculture, Bari, Italy.

5. Eizenberg, H., Plakhine, D., Dor, E., Hershenhorn, J., Kleifeld, Y., and Rubin, B. 2001. Phytotoxic root extract from resistant sunflower (Helianthus annuus L. cv. Ambar) inhibits Orobanche cumana development. Pages 190 192 in: Proc. 7th Int. Parasitic Weed Symp. A. Fer, P. Thalouran, D. M. Joel, L. J. Musselman, C. Parker, and J. A. C. Verkleij, eds. Nantes, France.

6. Eizenberg, H., Plakhine, D., Hershenhorn, J., Kleifeld, Y., and Rubin, R. 2003. Resistance to broomrape (Orobanche spp.) in sunflower (Helianthus annuus L.) is temperaturedependent. J. Exp. Bot. 54:1305-1311.

7. Encheva, V., and Shindrova, P. 1994. Broomrape (Orobanche cumana Wallr.) - a hindrance to sunflower production in Bulgaria. Pages 619-622 in: Proc. 3rd Int. Workshop Orobanche and Related Striga Res. A. H. Pieterse, J. A. C. Verkleij, and S. J. ter Borg, eds. Royal Tropical Institute, Amsterdam, The Netherlands.

8. Goldwasser, Y., Hershenhorn, J., Plakhine, D., Kleifeld, Y., and Rubin, B. 1999. Biochemical factors involved in vetch resistance to Orobanche aegyptiaca. Physiol. Mol. Plant 
Pathol. 54:87-96.

9. Goldwasser, Y., and Kleifeld, Y. 2002. Tolerance of parsley varieties to Orobanche. Crop Prot. 21:1101-1107.

10. Goldwasser, Y., Kleifeld, Y., Plakhine, D., and Rubin, B. 1997. Variations in vetch (Vicia spp.) response to Orobanche aegyptiaca. Weed Sci. 45:756-762.

11. Hershenhorn, J., Goldwasser, Y., Plakhine, D., Herzlinger, G., Golan, S., Russo, R., and Kleifeld, Y. 1996. Role of pepper (Capsicum annuum) as a trap and catch crop for control of Orobanche aegyptiaca and O. cernua. Weed Sci. 44:948-951.

12. Hoagland, D. R., and Arnon, D. I. 1950. The water culture method for growing plants without soil. Calif. Exp. Stn. Circ. 347.

13. Katzir, N., Portnoy, V., Tzuri, G., CastejonManoz, M., and Joel, D. M. 1996. Use of random amplified polymorphic DNA (RAPD) markers in the study of the parasitic weed Orobanche. Theor. Appl. Genet. 93:367-372

14. Labrousse, P., Arnaud, M. C., Serieys, H., Berville, A., and Thalouarn, P. 2001. Several mechanisms are involved in resistance of Helianthus to Orobanche cumana Wallr. Ann. Bot. 88:859-868.

15. Parker, C., and Dixon, N. 1983. The use of polyethylene bags in the culture study of Striga spp. and other organisms on crop roots.
Ann. Appl. Biol. 103:485-488.

16. Parker, C., and Riches, C. R. 1993. Parasitic Weeds of the World: Biology and Control. CAB International, Wallingford, UK.

17. Serghini, K., Perez de Luque, A., Munoz, M. C., Torres, L. G., and Jorrin, J. V. 2001. Sun flower (Helianthus annuus L.) response to broomrape (Orobanche cernua Loefi.) parasitism: induced synthesis and excretion of 7-hydroxylated simple coumarins. J. Exp. Bot. 52:2227-2234.

18. Sukno, S., and Fernandez, J. M. 2001. Temperature effect on the disease reactions of sunflower to the infection by Orobanche cumana. Plant Dis. 85:553-556. 